\title{
Profesyonel Turist Rehberlerinin Kişilik Özellikleri İle Sundukları Hizmet Kalitesi Arasındaki İlişki ${ }^{1}$
}

\author{
Aybüke ÖZSOY ${ }^{2}$ ve Ahmet TAYFUN ${ }^{3}$
}

Öz

Turist rehberlerinin birer turizm temsilcisi olarak turistlerin memnuniyet algisı ve yeniden ziyaret etme niyeti üzerindeki etkisinin fark edilmesiyle beraber mesleğe yönelik yapılan araştırmalar ve bu alana yönelik geliştirme faaliyetleri artmıştır. Araştırmanın amacı profesyonel turist rehberlerinin kişilik özellikleri ile sergiledikleri performans arasında bir farklılaşma olup olmadığını belirlemektir. Bu kapsamda performans düzeyinin turistlerce nasıl algılandığını tespit ederek bu performansın hizmet kalitesine nasıl yansıdığını belirlemektir. Bu amaçla kişilik özelliklerini ölçen Beş Faktör Kişilik Ölçeği ve algilanan hizmet kalitesini ölçen SERVPERF Ölçeği, 13 turist rehberi ve 475 turiste uygulanmıştır. Araştırma neticesinde kişilik özellikleri boyutları ile hizmet kalitesi boyutları arasında anlamlı bir ilişsi olduğu tespit edilmiştir. Boyutlar incelendiğinde turistlerin, turist rehberlerinin dış görünüşünü, tur esnasında kullandığı ekipmanlarını ifade eden somut özellikler boyutuna yönelik olan kalite alg1sı turist rehberlerinin duygusal denge (dengesizlik) ve empati özelliğine göre olumsuz yönde etkilenmektedir. Turist rehberinin dışa dönük kişilik özelliğinin arttıkça, turistlerin hizmet kalitesi boyutlarından algıladığ1 empati özelliği olumsuz yönde seyretmektedir. Bir diğer kişilik özelliği geçimlilik (uyumluluk) incelendiğinde bu özelliğin arttıkça turistlerin güvenilirlik, heveslilik, güven ve empati algisının olumlu yönde etkilendiği görülmüştür. Yine profesyonel turist rehberlerinin sorumluluk özelliği arttıkça turistlerin, rehberlere yönelik alg1ladığ1 güvenilirlik, güven ve empati algısı olumlu etkilenmektedir. Bu kapsamda gelecek çalısmalarda örneklem sayısının çoğaltılarak daha fazla turist ve turist rehberiyle iletişim sağlanabilir.

Anabtar Kelimeler: Turist Rehberi, Kişilik Özelliği, Hizmet Kalitesi.

\section{The Relationship between the Personality of Professional Tourist Guides and the Quality of Service Offered}

\begin{abstract}
As tourist guides have been recognized as tourism representatives, the impact of tourism on the perception of satisfaction and the intention of re-visiting has increased the research and development activities for the profession in recent years. The aim of the study is to determine whether there is a relationship between the personality traits and performance of professional tourist guides. In this context, determining how the performance level is perceived by tourists and determining how this performance is reflected in service quality. For this purpose, the Five Factor Personality Scale, which measures the personality traits, and the SERVPERF Scale, which measures the perceived service quality, were applied to 13 tourist guides and 475 tourists. As a result of the research, it was found that there was a significant relationship between the dimensions of personality traits and service quality. When the dimensions are examined, the perception of quality towards the dimension of concrete features expressing the external appearance of the tourist guides and the equipment used during the tour is negatively affected by the emotional stability (imbalance) and empathy characteristics of the tourist guides. As the extraversion personality of the tourist guide increases, the empathy that tourists perceive from the dimensions of service quality is unfavorable. It was observed that the perception of reliability, enthusiasm, trust and empathy of tourists was positively affected as the agreeableness (compatibility) increased. As the conscientiousness of professional tourist guides increases, the perception of reliability, trust and empathy perceived by the tourists towards the guides is positively affected. In this context, the number of samples can be increased in future studies and communication with more tourists and tourist guides can be provided.
\end{abstract}

Key Words: Tourist Guide, Personality Trait, Quality of Service

\section{Atıf İçin / Please Cite As:}

Tayfun, A. ve Özsoy, A. (2020). Profesyonel turist rehberlerinin kişilik özellikleri ile sundukları hizmet kalitesi arasındaki ilişki. Manas Sosyal Araştırmalar Dergisi, 9(2), 1101-1116.

Geliş Tarihi / Received Date: 10.09.2019

Kabul Tarihi / Accepted Date: 27.12.2019

\footnotetext{
${ }^{1}$ Bu çalıșma, Aybüke ÖZSOY’un yüksek lisans tezinden üretilmiștir.

2 Arş. Gör. - Nevşehir Hacı Bektaş Veli Üniversitesi Turizm Fakültesi, aybuke.ozsoy@nevsehir.edu.tr ORCID: 0000-0001-6906-5679

3 Prof. Dr. - Kırgızistan-Türkiye Manas Üniversitesi Turizm ve Otelcilik Yüksekokulu, ahmet.tayfun@manas.edu.kg ORCID: 0000-0001-7485-0663
} 


\section{Giriş}

Turizm sektörü ülkeler için önem arz eden bir gelir kaynağı niteliğindedir. Turistler ise bu sektörün kaynak sağlayan başlıca unsurudur. Turizm olgusunu oluşturan her bir faaliyet talepleri karşılamak adına ortaya konulmaktadır. Turist seyahat ettiği bölgede, alışı olduğu çevreden farklı bir yerde olduğundan yardıma ihtiyaç duyacaktır. Bu yardımın sağlanması bölge halkının yanı sıra öncelikle turu düzenleyen seyahat acentesine ve bunun yanı sira ülke ve acente temsilcisi olarak kabul edilen turist rehberlerine bağlıdır.

Turist rehberleri ülkelerini ziyaret eden turistlerin tatillerini memnun bir şekilde geçirmesinde, ülkeyi tekrar tercih etmesinde ve müşteri sadakati konusunda oldukça etkili olmaktadır. Bunun yanında turistler, tatilleri boyunca kaybolma riskine karşı, can ve mal güvenlikleri ve gezecekleri bölgeler hakkında detaylı bilgiler edinmek için, belirli bir zamanı kapsayan ve belirlenmiş bir bütçe ile tatillerini geçirdikleri yerlerde gezilebilecek bütün turistik ziyaret noktalarına ulaşmak için en iyi hizmeti talep etmektedirler (MEB, 2013, s. 7). Rehber turistlerle yüz yüze ilişki kurarak yol gösterme görevini üstlenirken güven unsuru doğal olarak oluştuğundan ayrıca bir öneme sahiptir. Dolayısıyla bütün bu imkânları sağlayabilecek olan profil turist rehberleri olarak ortaya çımaktadır.

Turizm olgusu içerisinde yer alan turist rehberliğinin, turist deneyimine olan katkısı diğer turizm ile alakalı meslek gruplarına kıyasla fark edilir bir şekilde gelişme göstermektedir (WFTGA, 2019). Seyahatler boyunca karşı karşıya kalınabilecek tüm problemleri çözüme kavuşturabilecek, tur öncesinde tüm plan ve programlamayı üstlenebilecek ve gezi boyunca muhtemel her durumu organize edebilecek bir kişiye duyulan gereksinim turlarda rehbere olan ilgiyi arttırmıstır.

Bir ülkeden turistlerin memnun bir şekilde ayrilmalarında rol oynayan faktörlerden biri de turist rehberleri tarafindan doğru ve yeterince bilgilendirilmeleridir. Turistin ön yargılarının değişmesinde, yanlışların düzeltilmesinde ve eksik bilgilerin tamamlanmasında rehberin sunumu, ülkeyi tanıtması, ilgili kurumlara atıfta bulunması ve sıcak iletişim kurması oldukça önemlidir. Özetle ülkenin tanıtımından, turistin tatilinden doyum sağlamasına, olumsuz ön yargılarının silinmesine kadar birçok konuda rehberlik mesleği bir görev üstlenmektedir. Turist rehberlerinin performansı turun iyi geçmesi açısından oldukça önem arz etmektedir. Turist rehberi, grup enerjisi, motivasyon ve kültürel yapı gibi konularda çok iyi bir eğitim almış olması gerekmektedir. Rehberin; aracı, sosyal, iletişim kurucu, yorumlayıcı ve sorumluluk gibi bir takım rolleri vardır (Randall ve Rollins, 2009, s. 359). Rehberin asli görevi bilgi vermekten ziyade konuşma ortamı yaratmaktır (Cohen, Ifergan ve Cohen, 2002, s. 922).

Rehberlik alanında hazırlanan çalısmalar genel itibariyle rehberin performansını ölçen ya da rehberin rollerine odaklanan çalışmalar olmuştur. Bu sebeple çalısma hem turist rehberlerinin kişilik özelliklerini belirlemeye hem de turistlerin çeşitli kişilik özelliklerine sahip turist rehberlerine yönelik memnuniyetini ölçmeye imkân yaratmaktadır. Turistlerin memnuniyetine bağlı olarak da hizmet kalitesinin belirlenmesine yardımc1 olmaktadır. Turist rehberlerinin performansının ziyaretçiler aracilığılla belirlenmesi ve bu performansın hizmet kalitesine olan etkisinin fark edilmesi gelecek zaman içinde bu mesleğin gelişmesine imkân yaratacaktır. Bu çalışma daha iyi bir hizmet sunulması, sorunların tespit edilmesi açısından rehberlere kaynak olabilir.

Profesyonel turist rehberliği mesleğinin ülkeler için önem arz etmesi bu çalışmanın hazırlanmasına zemin yaratmıştır. $\mathrm{Bu}$ doğrultuda Türkiye'deki profesyonel turist rehberlerinin kişilik özellikleri ile sergiledikleri performans arasında nasıl bir ilişki olduğunu belirlemek bu çalışmanın amacını oluşturmaktadır. Bu kapsamda performans düzeyinin yerli turistlerce nasıl algılandığını tespit edip bu performansın hizmet kalitesine ne şekilde yansıdığı belirlenmeye çalışılmıştır ve profesyonel turist rehberlerinin kişilik özelliklerinin belirlenip turistlerin, profesyonel turist rehberlerinden aldıkları hizmet sonucunda alg1ladıkları memnuniyet düzeyi somut özellikler, güvenilirlik, heveslilik, güven ve empati olarak beş boyutta incelenmiştir.

\section{Kişilik Özellikleri}

Kişilik bireylerin yaşam biçimidir, kişinin doğumundan ölümüne kadar olan yaşam süresinde devam eden dinamik süreci kapsar (Zel, 2001, s. 411). Kişilik, insanları birbirlerinden ayıran ve kişilerin benliklerine özgü tutumların, duyguların ve düşüncelerin meydana getirdiği bir bütündür (Macionis, 2012). Kişilik bireyin sahip olduğu işi ve yaşadığı bölgeyi anlamlandırmasında ve değerlendirmesinde oldukça büyük bir öneme sahiptir (Özkalp, 2001, s. 52). Sahip olunan iş bireyin kişilik nitelikleriyle ve yetenekleriyle uyumlu olduğunda iş doyumu gerçekleşmektedir. İnsanlar kendilerinin karakteristik özelliklerini ve 
marifetlerini işlerine uyarladığında verimliliğe ulaşmaktadırlar. Profesyonel turist rehberleri de meslekleriyle ilgili yerine getirilmesi gereken görev, sorumluluk ve rollerin yanı sıra buna kendi özel yaşantılarındaki rollerinin de eklenmesi sonucunda çok farklı kişilik özellikleri ortaya çıkmaktadır. Entelektüel ve kültürel anlamda kendini geliştirmiş, sahip olduğu bilgiyi açık ve akıcı bir biçimde sunabilme ve çevresindekilerle etkileşimini etkin bir biçimde yürütebilme yetisine sahip bir turist rehberi turizm camiası içerisinde önem taşımaktadır (Eser, Şahin ve Çakıc1, 2018, s. 84).

Turist rehberlerinin kişilik özellikleri ile iş yaşamları doğru orantılıdır. Diğer bir deyişle kişinin mesleği ve kişilik özellikleri ile örgüt kültürü, kuralları, ast üst ilişkileri, yapısı ve atmosferi arasında birbiriyle alakalı bir iletişim meydana gelmektedir. Birey kişilik özelliklerini çalıştı̆ı ortama yansıtmaktadır. Buna istinaden rehberlerin kişilik özelliklerinin mesleğin gerektirdiği özelliklerle uyum halinde olması gerekmektedir. Mesleki uyum turist rehberinin performansını doğrudan ve dolaylı olarak etkileyerek gerçekleştirilen turun verimli ve güzel geçmesini sağlayabilir. Turist rehberinin kişilik özelliklerinin işine uygun olmaması, yaptığ1 işi sevmemesine ve zevk almamasına neden olur bunun yanında manevi tatminsizlik yaşamasına sebep olmaktadır. Başka bir ifadeyle turist rehberlerinin rehberlik yapma tarzı kişilik özellikleri, algı düzeyleri ve eğitim seviyeleri ile yakından ilişkilidir (Tsaur ve Teng, 2017).

Literatür incelendiğinde rehberlerde bulunması gereken kişilik özelliklerini konu edinen çalışmalar oldukça az sayıda gözlenmektedir. Bu çalışmalar, daha çok rehberlerin hangi özelliklere sahip olması gerektiğini belirtmektedir. Örneğin Yıldız, Kuşluvan ve Şenyurt (1997, s. 11) rehberlerin bilgiye ulaşma ve etkileşim yeteneği, plan yapma, organize etme, lider olma, koordinasyon ve denetim yeteneği, müşterileri anlama ve onlara saygılı olma, dışadönük, eğlenceli ve sosyal olma, mesleği ile ilgili teknik bilgi ve becerilere sahip olması gerektiğini bunun yanında sakin ve dirençli olma, dürüst davranma gibi özelliklerini de üzerinde barındırması gerektiğini ifade etmişlerdir. Bir diğer çalışmada rehberlerde bulunması gereken özellikler şöyle ifade edilmiştir; topluluk önünde konuşabilme veya topluma hitap edebilme becerisine sahip olmalı, aynı zamanda eğlenceli bir karakter yapısına sahip olmalıdır (Ap ve Wong, 2001, s. 551). Rehberlerin yaptıkları işi benimsemesi, içselleştirmesi, sevmesi bunun yanında yaratıcı, dinamik, araştırmac1, tertipli ve disiplinli olması, meslek ve genel kültür bilgisi açısından yeterli olması, yabancı dil bakımından kendini yetiştirmesi bunu yaparken de ana dilini güzel bir biçimde kullanması, topluluk önünde etkileyici ve güzel konuşabilmesi gerekmektedir (Değirmencioğlu, 2003, s. 23).

Beş Faktör Kişilik modeli, 2018 yıllnda Kabakulak tarafından turist rehberlerinin kişilik özelliklerinin mesleki davranış ve iş tatminine etkisini belirlemeye yönelik olarak, Türkiye'deki turist rehberleri üzerinde kullanılmıştır. Araştırma sonuçlarına bakıldığında rehberlerin mesleki tutumlarının ve iş tatminlerinin yüksek düzeyde olduğu ortaya çıkmıştır. Kişilik özellikleri boyutlarından da duygusal denge özelliği haricinde diğer tüm kişilik özellikleri rehberlerde yüksek düzeyde tespit edilmiştir. Turist rehberlerinin kişilik özelliklerinin meslekteki davranışları ve iş tatminleri üzerinde anlamlı bir etkisinin olduğu görülmüş ve turist rehberlerinin mesleki tutumları ile iş doyumları arasında anlamlı bir ilişkinin olduğu tespit edilmiştir (Kabakulak, 2018, s. 144).

\section{Hizmet Kalitesi}

Grönroos (1984) hizmet kalitesini, "müşterilerin aldığ1 hizmete yönelik algilarının, beklentileriyle karşılaştırıldıktan sonra yaptıkları değerlendirme sürecinin çıtııı" olarak ifade etmektedir. Başka bir tanımda hizmet kalitesi, istenilen kalite ile karşılaşılan kalitenin karşılaştırılması olarak ifade edilmiştir (Teas, 1993, s. 27). Parasuraman, Zeithaml ve Berry (1994, s. 112) hizmet kalitesini, müşterilerin birden çok aldığ1 hizmet sonrasında meydana gelen bir düşünce olarak belirtmiştir.

Turistlerin gittikleri bölgelerden istedikleri verimi almaları ziyaret edilen destinasyonun sunduklarının yanı sıra büyük oranda rehberlerin performansına bağlıdır. Dolayısıyla turist rehberinin sunduğu hizmetin kalitesi turistler için öncelikli sırada gelmektedir. Rehberlik hizmeti ne denli kaliteli olursa ve ziyaretçinin beklentisini karşılarsa o düzeyde ziyaretçi memnuniyeti sağlanmış olacaktır. Ülkeyi temsil etme açısından da profesyonel turist rehberlerinin önemi oldukça fazladır. Turist rehberlerinin birer turizm temsilcisi olarak turistlerin memnuniyet algisı ve yeniden ziyaret etme niyeti üzerine olan etkisinin fark edilmesiyle beraber son yıllarda gerek turist rehberliği eğitimi gerekse mesleğe yönelik yapılan düzenlemeler ve geliştirme faaliyetleri artmıstır.

Literatürde turist rehberliği mesleğinde hizmet kalitesini ölçen çalışmalar incelendiğinde yerli ve yabancı alan yazının zayıf olduğu görülmüştür. Genel olarak turizm alanında hizmet kalitesi çalışmaları oldukça yaygınken turist rehberliği alanında yeterli çalısmaya rastlanmamıştır. Rehberlik alanında 
hazırlanan çalışmalar genellikle rehberin performansını ölçen veya rehberin rollerine dikkat çeken çalş̧malar olmuştur.

Turist rehberliği mesleğinde hizmet kalitesini ölçen çalşmalar incelendiğinde yerli ve yabancı alan yazının zayıf olduğu görülmüştür. Genel olarak turizm alanında hizmet kalitesi çalışmaları oldukça yaygındır. Örneğin Yılmaz’ın (2009, s. 81) otel endüstrisinde hizmet kalitesinin ölçümüne yönelik çalşmasında otel müşterilerinin, tüm hizmet kalitesi boyutlarında otellerden daha gelişmiş hizmet beklediği ancak bunun karşllğında, otel müşterilerinin maddi durumları puanlamada en düşük düzeyde olduğu ortaya çımıştır. Butnarua, Stefanica ve Maxim'in (2014, s. 677) konaklama işletmelerinde hizmet kalitesinin geliştirilmesine yönelik yaptığ çalışmada otel yöneticilerinin rekabet ortamında bulunduklarından dolayı fiyatlandırma, müşteriyle iletişim, tesis donanımı, hizmet çeşitliliği gibi sunulacak hizmetlere oldukça önem vermesi gerektiği savunulmuştur. Moisescu ve Gica (2014, s. 1201), seyahat acentelerinde verilen hizmetin kalitesini ölçmek amacıyla Romanya'daki bir seyahat acentesinin turlarında seyahat eden 286 turiste çevrimiçi anket uygulamıştır. Bulgulara göre turistlere karşı davranış biçimleri müssteri sadakatini büyük ölçüde etkilemektedir. Ban ve Ramsaran (2017, s. 143) ise Avustralya'daki ekolojik alanların hizmet kalitesi özellikleri incelemektedir. Bulgular, ekoturizmde üç ek boyutu ortaya çıkarmıştır. Bunlar: çevre dostu uygulamalar, eko-etkinlikler ve eko-öğrenmedir. Turistlerin ekoturizm alanındaki hizmet kalitesi algılarını değerlendirmeye yönelik yapılacak çalışmaların önemini ortaya çıkararak daha fazla deneysel araştırmayı teşvik etmektedir.

Turizmin birçok alanında hizmet kalitesini ölçen yerli ve yabancı çalşmalar mevcutken turist rehberliği alanında yeterli çalısmaya rastlanmamıştır. Örneğin; Müküs (2009)'ün Doğu Anadolu Bölgesi'nde faaliyet gösteren turist rehberlerinin yeterliliğini ve turist memnuniyetini ölçmek üzere hazırladığ çalsşmada turist rehberlerinin bilgi ve yetenek seviyelerini, kişilik ve karakter niteliklerini önemseyerek kişilerin turist rehberlerinden beklentileri, önem ve performanslarını kiyaslayarak ortaya koymuştur. Turist rehberlerine aldıkları mesleki eğitimin yeterli olup olmadı̆̆ anket yöntemiyle sorulmuştur. Doğu Anadolu Bölgesinde turizmin hâkim olduğu bölgeler olan Van, Ağr1, Kars ve Erzurum illerindeki yerli ve yabancı turistlerin katıldığı turlardaki rehberlerin nitelikleri, performansı ve özelliklerinin nasıl olduğu ve önem-performans düzeyleri belirlenmeye çalısıllmıştır. Eğitim açısından incelendiğinde dil eğitimi özellikle yabancı ziyaretçilerin çeşitliliği göz önünde bulundurularak, İngilizce dışında Rusça, Japonca, Çince ve Almanca gibi dillerin de mesleki eğitimler esnasında ek bir yabancı dil düşünülmesi gerekliliği ortaya çıkmıştır. Turist rehberlerinin almış oldukları eğitim bazı alanlarda yeterliyken bazı alanlarda mesleklerini icra ederken yetersiz olduğu tespit edilmiştir.

Mak, Wong ve Chang (2010), Macaudaki turist rehberlerinin hizmet kalitesine etki eden faktörleri belirlemek üzere yaptıkları çalısmada 5 katılımcıya yarı yapılandırılmış görüşme uygulamışlardır ve sonucunda rehberlerin performansında bir uygunsuzluk söz konusu olduğunda turizm ve ev sahibi destinasyon bundan kötü etkilenmektedir. Arslanturk, Altunöz ve Çalık (2013, s. 111) turist rehberleri tarafindan sunulan hizmetin kalitesini tespit etmek amacıyla, SERVQUAL hizmet kalitesi ölçüm modelini bir acentenin yurt dışında düzenlediği bir turuna katılan misafirler üzerinde uygulamıştır. Bulgulara göre, genel olarak hizmet kalitesi algısının yüksek olduğu ortaya çıkmıştır bunun yanı sıra empati boyutunda alg1lanan hizmet kalitesi seviyesi kalite beklentisinin altında kalmıştır. Hizmet kalitesi beklentisine en yakın olan boyut ise fiziksel özellikler boyutudur. Hizmet alan misafirlere göre kalite boyutları arasından en düşük öneme sahip olan boyut heveslilik (ilgi) boyutudur. Turizm sektöründe diğer hizmet sektörlerinde olduğu gibi müşterinin en hassas olduğu durumlardan biri kendileriyle ilgilenilmesi ve işlerinin çabucak yerine getirilmesi beklentisi olduğu düşünüldüğünde bu sonuç oldukça ilginçtir.

\section{Kişilik Özellikleri ve Hizmet Kalitesi}

Hizmet gerektiren işlerde, çalışanların ruh halleri ve başkalarıyla kurdukları iletişim önemlidir. İşletmeler de buna dikkat ederek, kişilik ve iş arasındaki uyuma özen göstermektedir. Örneğin, otellerde müşteriler ile karşıllklı iletişsimde bulunan personellerin yumuşak başlı kişiler olmaları gerektiği öne sürülmektedir (Costen ve Barrash, 2006). Turizm sektöründe de yüz yüze karş1lıklı ilişkilerin yoğun olarak gerçekleştiği göz önünde bulundurulduğunda kişilik, bireyin hitap ettiği insanlarla kurduğu iletişimi etkilediği için, çalışanlar ve müşteriler arasındaki ilişkinin kalitesini de etkilemektedir (Temizkan ve Arr, 2019, s. 71).

Turizm içerisinde önemli bir yeri olan profesyonel turist rehberlerinin de tur boyunca turistlere sağladığı hizmetin niteliği memnuniyeti etkileyen bir faktör olarak düşünülmektedir. Profesyonel turist rehberlerinin yaptıkları işin, kişilik özellikleri ile uyum göstermesi halinde işini sevmesi, bağlllık duyması 
sonucunda daha iyi sonuçlar elde edileceği düşünülmektedir. Örneğin, Özoğul (2017) tarafından yapılan bir çalışmada, deneyime açıklık, dışadönüklük ve sorumluluk özelliklerinin mesleğe yönelik duygusal bağlılık üzerinde pozitif yönde anlamlı etkilere sahip olduğu belirtilmiştir. Turist rehberinin kişilik özelliklerinin turdaki performansına yansıması durumu turistlerin memnuniyet algısını değiştirebilmektedir. Turist rehberlerinin performansı kişilik özelliklerine bağlı olarak arttıkça turistin katıldığı geziden aldığ1 tatmin oranı da yükselebilir. Katılımcıların tatmin düzeyi de hizmet kalitesi algısını etkilemektedir. Bak (2015) tarafindan Kapadokya Bölgesi’nde hazırlanan çalısmada Turist rehberlerinin performansının turist tatminini etkilediği ortaya çıkmıştır. Turistlerin yaşadıkları yerden farklı bir bölgeye gittiklerinde kendilerini yabancı gibi hissetmemeleri, gezdikleri ülkelere uyum sağlayabilmeleri, bölge hakkında bilgi edinmeleri ve bölgeden memnun bir şekilde ayrılmaları hususunda turist rehberlerinin gösterdiği performansın etkisi oldukça önemlidir.

Son dönemlerde, tüketici memnuniyetini etkileyen faktörlere farklı bakış açılarıyla değinilmekte ve tüketici davranışlarında kişisel özelliklere yönelik çalışmalar artış göstermektedir. Turizm alanında tüketicilerin memnuniyetini sağlamak, hizmet veren tüm birimlere bağlıdır. Bu alanda görülen hizmet anlayışı misafir memnuniyetine odaklı olduğu için sektörde hizmet veren kişilerin sahip oldukları kişilik özellikleri, memnuniyeti en üst düzeye çıkarma bakımından önemli bir unsurdur (Pelit, Türkmen ve Yarmac1, 2010, s. 12). Pelit ve diğerleri (2010), bir otel işletmesi çalışanlarına yönelik yaptığı araştırmada, işgörenlerin kişilik özelliklerinin, diğer çalışanları, yöneticileri ve müşterileri etkileceğine değinmiştir. Buna benzer başka bir düşünce de, Serçeoğlu (2013, s. 5269) tarafindan ortaya atılmıştır. Hazırladığı çalışmada otel işletmelerinde çalışan bireylerin kişilik özelliklerinin hizmet verme yatkınlŭ̆ üzerindeki etkisini incelemiş ve 11 adet otel işletmesinde hizmet sunan işgörenleri araştırma kapsamına almışıtı. Sonuçlara bakıldığında, kişilik özellikleri ile hizmet verme yatkınlğı arasında duygusal denge haricinde kalan tüm boyutlarda pozitif yönlü ve anlamlı bir ilişkiye ulaşılmıştır. Görüldüğü üzere turizm gibi hizmet yoğunluklu sektörlerde kaliteli hizmet sağlamak, çalışanların durumlarına büyük oranda bağlıdır. Soyut bir özellik taşıyan hizmet, hizmeti sunan bireylerin kişiliğinde, dış görünüşünde, tutum, hal ve hareketlerine yansımakta, bununla birlikte temsil edilen işletmenin müşterilere karşı imajın belirlemektedir (Hartline ve Jones, 1996). Hizmet sunan kişi ile müşteri arasındaki etkileşim, hizmet değiş tokuşunun kalbi olarak görülmektedir (Donavan, 2000). Lee-Ross'a (2003) göre hizmeti sunan kişi ile hizmeti alan arasındaki etkileşimin yönetilmesinde en etkili unsurun doğru iş için uygun insanı seçmektir. Bu anlamda, birçok araştırmacı, hizmet sunumunun sağlandığı tüm işlerde çalışanların seçim ölçütleri arasında kişiliğin en önemli kriter olduğunu savunmaktadır (Schnedier ve Bowen 1995). Brown ve diğerleri (2002) de hizmet personelinin müşteri odaklllı̆ı, işgörenin ve yöneticinin performansının değerlendirilmesinde kişisel özelliklerin rolü olduğunu ileri sürmüşlerdir. Başka bir çalışmada ise; kişilik, cinsiyet ve turist davranışları arasındaki ilişki incelenmiş ve bu üç değişken arasında anlamlı ilişkinin bulunduğu keşfedilmiştir (Frew ve Shaw, 1999, s. 193). Çalışmalardan anlaşılacağı üzere, hizmet kalitesinin söz konusu olduğu tüm işlerde çalışacak kişilerin seçim ölçütleri arasında kişilik en önemli unsur olarak görülmelidir (Serçeoğlu, 2013, s. 5253). Bu görüşler, seyahat acenteleri açısından ele alındığında, hizmet sektörü içerisinde yoğun olarak yer alan turist rehberliği mesleğini icra edecek kişilerin de kişilik özelliklerinin önemli olduğu düşünülmektedir. Çalışmalar ışı̆̆ında, hitap ettiği gruba karşı tutum ve davranışları ve tura katılan misafirlerin memnuniyeti, turist rehberinin kişiliğinin bir yansıması olarak karşımıza çıkabileceğini söylemek yanlış olmayacaktır.

Bu kapsamda turist rehberlerinin kişilik özelliği ile turistlerin hizmet kalitesi alg1sı arasındaki ilişkiyi tespit etmek amaciyla aşağıdaki hipotez oluşturulmuştur;

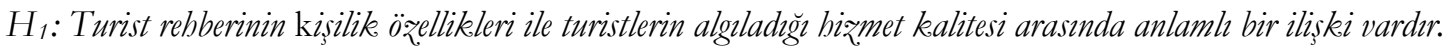

Hizmet kalitesi algısının, turist rehberlerinin kişilik özelliğine bağlı olarak farklllık göstereceği varsayılmaktadır. Bunun yanı sıra turistlerin hizmet kalitesi algilarını etkileyebilecek diğer bir unsur da demografik özelliklerdir. Bu kapsamda yapılan çalışmalar da turistlerin bir takım demografik özelliklerin hizmet kalitesi algılarını değiştireceğini öne sürmektedir.

Çelik'in (2018) butik otellerde sunulan hizmet kalitesinin ölçülmesine yönelik yaptı̆̆ çalışmada, algılanan hizmet kalitesi turistlerin demografik özelliklerine göre kısmen farklılaşmaktadır. Kadın katılımcıların hizmet kalitesi boyutlarından fiziksel özellikler, güvenilirlik ve güven boyutları algıları erkek katılımcılara kıyasla daha yüksek belirlenmiştir. Bu bağlamda, kadın turistlerin hizmet aldıkları otelin görünümü, hizmetlerin güvenilirliği ve çalışanların güven duygusu vermesi konularındaki algıları daha yüksektir. 
Yee, Ramachandran, Shuib, Johari ve Afandi (2018) tarafindan Kuala Lumpir'de bulunan Negara hayvanat bahçesinin bir bölümünde yer alan dev pandaların koruma merkezinde yapılan araştırmada, turistlerin demografik özelliklerinden olan yaş unsurunun algılanan hizmet kalitesini, tekrar ziyaret etme niyetini ve başkalarına öneri eğilimini etkilediği ortaya konulmuştur. Fettahlıŏglu, Polat ve Demir (2016) bir otel işletmesinde konaklayan turistlerin, genel olarak otellerden bekledikleri hizmet kalitesi ile deneyimlediği hizmet kalitesi arasında bir farkın olup olmadığının tespitine yönelik yaptıkları çalışmada, hizmet kalitesinin gelir düzeylerine göre farklılaşmadığı, eğitim düzeyine göre ise kısmen farklılaşttğ1 sonucuna varılmıştır (Fettahlıoğlu Polat ve Demir, 2016, s. 849).

Alan yazındaki çalışmalar ışığında turistlerin hizmet kalitesi algılarının demografik özelliklerine göre farklılaşmasına yönelik hipotezler şu şekilde sıralanmaktadır:

$\mathrm{H}_{2}$ : Turistlerin biżmet kalitesi algzlar demografik özelliklerine göre anlaml bir șekilde farkhlasmaktader.

$\mathrm{H}_{2 a}$ : Turistlerin hizmet kalitesi algzlar cinsiyetlerine göre anlamli bir șekilde farkhlalasmaktadr.

$H_{2 b}$ : Turistlerin biżmet kalitesi algzlar medeni durumlarna göre anlaml bir şekilde farkhllasmaktader.

$\mathrm{H}_{2 c}$ : Turistlerin bizmet kalitesi algzlar daha önce rehberli bir tura kathlm durumlarna göre anlamh bir şekilde farkhlasmaktader.

$H_{2 d}$ : Turistlerin hižmet kalitesi alguları yaslarna göre anlamh bir sekilde farkhlasmaktadrr.

$H_{2 e}$. Turistlerin hižmet kalitesi algzlar mesleklerine göre anlaml bir şekilde farkllalasmaktadrr.

$H_{2 f}$. Turistlerin bizmet kalitesi algzlar eğitim durumlarna göre anlaml bir şekilde farkhlaşsmaktadrr.

\section{Yöntem}

Profesyonel turist rehberlerinin kişilik özelliklerinin hizmet kalitesi ile ilişkisini belirlemek üzere hazırlanan araştırmada, nicel araştırma yöntemi kullanılmıştır.

\section{Evren - Örneklem}

Çalışmanın evreni 2018 ve 2019 yılları içerisinde Ankara çıkışı turlarla turistik faaliyet gösteren yerli turist grupları ve profesyonel turist rehberleridir. Belirli bir bölge seçilmeyip seyahat acentelerine bağlı olarak günübirlik veya konaklamalı turlar ile seyahat etmekte olan turist gruplarından ve her bir gruptan sorumlu profesyonel turist rehberlerinden bilgi alınmıştır. Ankara çıkışı turlar ile hareket eden turist sayısına ilişkin herhangi bir istatistiki bilgiye ulaşılamamakla birlikte turist sayısına ilişkin evren büyüklüğü sınırlı değildir. Araştırmalarda evreni temsil edecek 384 örneklem sayısı yeterli olmaktadır (Altunışık vd., 2012, s. 137). Örneklem seçiminde kullanılan yöntem olasıllğga dayalı olmayan yöntemlerden biri olan kolayda örnekleme yöntemidir.

Ankara Rehberler Odası'na 2019 itibariyle kayıtlı olan 836 turist rehberi bulunmaktadır. Bu sayısının 545'ini eylemli turist rehberleri oluşturmaktadır (TUREB, 2019). Bu sayı araştırmanın turist rehberi evrenini ifade etmektedir. Ankara'dan hareket eden turlarda 13 turist rehberi ve bu rehberlerle tura katllan 475 yerli turist araştırmanın örneklemini oluşturmaktadır. Rehber örnekleminin sayısı turlara katılan turist örneklem sayısının doğal bir sonucudur. Her rehberin hitap ettiği turist sayısı yaklaşık 42 (yaklaşık bir otobüs) dir. Ölçülmek istenen, turistlerin memnuniyeti doğrultusunda hizmet kalitesidir ve turist rehberi örneklem sayısı büyüdükçe buna bağlı olarak turist örneklem sayısı da büyüme gösterecektir. Araştırmanın sınırlllı̆ı kaynak, zaman ve maliyet gibi sebeplerden dolayı anketlerin sadece yerli turistlere uygulanmış olmasidır.

\section{Veri Toplama Araçları}

Araştırmada kullanılan veri toplama aracı ise sosyal bilimler alanında yaygın olarak kullanılan anket tekniğidir. Profesyonel turist rehberlerinin sergiledikleri performans ve kişilik özellikleri anket tekniğiyle kolaylıkla ölçülebilir. Bunun yanında anket uygulanan turistler ve profesyonel turist rehberleriyle birebir karşlıklı iletişimle anket maddelerinin anlaşlır olması neticesinde daha verimli sonuçlar elde edildiği düşünülmektedir. Araştırmada kullanılan her bir anket iki bölümden oluşmaktadır. Anketin birinci bölümünde, katıllımcıların sosyo-demografik özellikleri belirlenmeye çalışılmışır.

Beş Faktör Kişilike Ölçeği. Demografik özelliklerin belirlenmesinden sonra kullanılan anket turist rehberlerine uygulanmıştır bu kapsamda orijinali Costa ve McCrae (1985) tarafından geliştirilen, Kabakulak (2018, s. 91) tarafindan da geçerlilik ve güvenilirliği test edilen Beş Faktör Kişilik Ölçeği kullanılmıştır. 
Profesyonel turist rehberlerin kişilik özellikleri, duygusal denge, dışa dönüklük, açıklık (yaşantıya), geçimlilik ve sorumluluk boyutlarıly belirlenmiştir.

SERVPERF Ölçeği. Turistlere uygulanan ölçek, SERVQUAL yöntemine alternatif olarak Cronin ve Taylor tarafindan 1992 yllında geliştirilen ve Aslantürk (2010, s. 51) tarafından geçerliliği ve güvenirliliği tekrar test edilen SERVPERF ölçeğidir. Bu yöntem, SERVQUAL'deki müşterilerin beklentileri ve algıları arasındaki farkı tespit etmek yerine; doğrudan müşterilerin algıladıkları performansı ölçmektedir (Koçoğlu ve Aksoy, 2012, s. 6). Turistlerin aldıkları hizmet sonucunda algıladıkları memnuniyet düzeyi somut özellikler, güvenilirlik, heveslilik, güven ve empati olarak beş boyutta incelenmiştir.

Tablo 1. Ölçeklerin Güvenirliğ

\begin{tabular}{lccc}
\hline & Ölçekler & Önerme sayılatr & Croanbach Alpha $(\alpha)$ \\
\hline Beş Faktör Kişilik Ölçeği & 30 &, 611 \\
SERVPERF & 22 &, 877 \\
\hline
\end{tabular}

Anketin turist rehberlerine uygulanan bölümü olan Beş Faktör Kişilik Ölçeğin Cronbach Alpha güvenirlik katsayısı 0,61 olarak belirlenmiştir. Anketin turistlere uygulanan SERVPERF Ölçeği Cronbach Alpha güvenirlik testi ise 0,87 olarak tespit edilmiştir. Güvenilirlik katsayısi; $0.60<\alpha \leq 0.80$ ise ölçek oldukça güvenilirdir, $0.80<\alpha \leq 1.00$ ise ölçek yüksek derecede güvenilir bir ölçektir (Özdamar, 2002, s. 673).

\section{Verilerin Analizi}

Uygulama alanındaki hedef kitlenin ölçme aracına verdikleri cevapların geri dönüşümünden sonra ilk olarak katılımcıların bireysel özelliklerine ilişkin bulgular frekans ve yüzde dağılımlarıyla ifade edilmiştir. Bunun yanı sıra kişilik özellikleri ve hizmet kalitesine ilişkin ölçekler frekans ve yüzde değerleriyle tanımlanmışır. Ayrıca, kişilik özelliklerinin ve hizmet kalitesinin katılımcıların bireysel özelliklerine göre karşılaştırılmasında veriler normal dağılıma uyduğu için parametrik testlerden iki grup için t testi, ikiden fazla grup için tek yönlü varyans analizi kullanılmıştır. Çalışmada her bir ölçeğe ilişkin alt boyutlar (değişkenler) arasındaki ilişkiler Pearson korelasyon analiziyle test edilmiştir.

\section{Bulgular}

Araştırmaya katılan turistlerin cinsiyet, yaş, medeni durum, eğitim durumu, meslek ve daha önce rehberli tura katılım durumuna ilişkin bilgiler Tablo 2'de belirtilmiştir.

Tablo 2. Turistlerin Demografik Özellikleri

\begin{tabular}{|c|c|c|c|}
\hline Demografik Ifadeler & Gruplar & $n$ & $\%$ \\
\hline \multirow{2}{*}{ Cinsiyet } & Kadin & 166 & 34,9 \\
\hline & Erkek & 309 & 65,1 \\
\hline \multirow{4}{*}{ Yaş } & 25- alt1 & 115 & 24,2 \\
\hline & $26-35$ & 141 & 29,7 \\
\hline & $36-45$ & 117 & 24,6 \\
\hline & 46 ve üstü & 102 & 21,5 \\
\hline \multirow{2}{*}{ Medeni durum } & Evli & 217 & 45,7 \\
\hline & Bekâr & 258 & 54,3 \\
\hline \multirow{3}{*}{ Eğitim durumu } & İlköğretim & 54 & 11,4 \\
\hline & Lise & 205 & 43,2 \\
\hline & Lisans & 216 & 45,5 \\
\hline \multirow{8}{*}{ Meslek } & Memur & 91 & 19,2 \\
\hline & Emekli & 36 & 7,6 \\
\hline & İşçi & 66 & 13,9 \\
\hline & İssiz & 31 & 6,5 \\
\hline & İşveren & 90 & 18,9 \\
\hline & $\ddot{O ̈ g ̆ r e n c i ~}$ & 111 & 23,4 \\
\hline & Esnaf & 39 & 8,2 \\
\hline & Diğer & 11 & 2,3 \\
\hline \multirow[t]{2}{*}{ Daha önce rehberli tura katıllım durumu } & Evet & 296 & 62,3 \\
\hline & Hayır & 179 & 37,7 \\
\hline TOPLAM & & 475 & 100 \\
\hline
\end{tabular}

Katılımcıların \%65,1'ni (309) erkekler, \%34,9’unu (166) ise kadınlar oluşturmaktadır. Turistlerin yaş ortalamaları incelendiğinde \%29,7'lik (141) bir oranla 26-35 yaş arasındaki kişilerden oluştuğu 
görülmektedir. Anket uygulanan turistlerin medeni durumları ise $\% 54,3$ oranında bekâr ve $\% 45,7$ oranında da evli olduğu ortaya çıkmıştır. Katıllımcıların \%43,2'si lise mezunudur bu oranı \%45,5'lik bir oranla üniversite mezunları takip etmektedir. Ankete katılanların büyük bir çoğunluğunu $(\% 23,4)$ öğrenciler oluşturmaktadır. Diğer katılımcıların meslek grupları ise sırasıyla kamu çalışanı $(\% 19,2)$, özel sektör işveren $(\% 18,9)$, işçi $(\% 13,9)$, esnaf $(\% 8,2)$, emekli $(\% 7,6)$, isssiz $(\% 6,5)$, diğer $(\% 2,3)$ 'dir. Araştırmaya katılanların daha önce rehberli bir tura katılma oranı ise \%62,3'tür.

Tablo 3. Turist Rebberlerinin Demografik. Özellikleri

\begin{tabular}{|c|c|c|c|}
\hline Demografik Ifadeler & Gruplar & $n$ & $\%$ \\
\hline \multirow{2}{*}{ Cinsiyet } & Erkek & 7 & $\overline{53,8}$ \\
\hline & Kadin & 6 & 46,2 \\
\hline \multirow{3}{*}{ Yaş } & $26-35$ & 4 & 30,8 \\
\hline & $36-45$ & 6 & 46,2 \\
\hline & $46-60$ & 3 & 23,1 \\
\hline \multirow{2}{*}{ Medeni durum } & Evli & 6 & 46,2 \\
\hline & Bekâr & 7 & 53,8 \\
\hline \multirow{2}{*}{ Eğitim durumu } & Lisans & 11 & 84,6 \\
\hline & Lisansüstü & 2 & 15,4 \\
\hline \multirow{3}{*}{ Rehberlik eğitimini alma durumu } & Bakanlık Kursu & 1 & 7,7 \\
\hline & Lisans & 11 & 84,6 \\
\hline & Yüksek Lisans & 1 & 7,7 \\
\hline \multirow{5}{*}{ Rehberlik yapılan dil } & İngilizce & 8 & 61,5 \\
\hline & Rusça & 1 & 7,7 \\
\hline & Almanca & 1 & 7,7 \\
\hline & Çince & 1 & 7,7 \\
\hline & Birden fazla dil & 2 & 15,4 \\
\hline \multirow{2}{*}{ Rehberlik mesleğinin nasıl icra edildiği } & Acenteye bağlı & 4 & 30,8 \\
\hline & Bağımsız & 9 & 69,2 \\
\hline \multirow{4}{*}{$\begin{array}{l}\text { Rehberlik mesleğinin ne kadar süredir icra } \\
\text { edildiği }\end{array}$} & $0-5$ yll & 2 & 15,4 \\
\hline & $6-10$ & 7 & 53,8 \\
\hline & $11-15$ & 3 & 23,1 \\
\hline & $16-20$ & 1 & 7,7 \\
\hline TOPLAM & & 13 & 100 \\
\hline
\end{tabular}

Ankete katılan turist rehberlerinin \%53,8’i (7) erkek iken \%46,2'si (6) kadındır. Rehberlerin yaşları incelendiğinde 36-45 yaş aralığında bulunanların oranı \%46,2'dir. Katılımcıların 7'si bekâr iken 6'sı evlidir. Rehberlik eğitiminin alınma durumuna bakıldığında rehberlerin \%84,6'sı lisans eğitimi ile çalışma kartı sahibi olmuştur. Bu oranı birer kişi ile bakanlık kursu ve yüksek lisans eğitimi takip etmektedir. Turist rehberlerinin çalışma dilleri incelendiğinde büyük oranın $(61,5)$ İngilizce diline ait olduğu görülmektedir. Araştırmaya katılan turist rehberlerinin \%69,2'si (9) bir yere bağlı olmadan bağımsız çalışırken \%30,8’i (4) seyahat acentelerine bağlı olarak faaliyetlerini sürdürmektedir. Turist rehberliği mesleğinde deneyim süreleri incelendiğinde rehberlerin \%53,8'si 6 ila 10 yıldır bu mesleği icra etmektedir.

\section{Kişilik Özellikleri ve Hizmet Kalitesi Arasındaki İlişki}

Turist rehberlerinin kişilik özellikleri ile turistlerin hizmet kalitesi algısı arasındaki ilişki ve değişkenler arasındaki korelasyon katsayıları Tablo 4'te verilmiştir.

Tablo 4. Kişilik Boyutlarn ile Hizmet Kalitesi Boyutları Arasındaki Korelasyon Analiz̨i Sonucları

\begin{tabular}{|c|c|c|c|c|c|c|c|c|}
\hline Boyutlar & $\mathbf{n}$ & Ortalama & $\begin{array}{c}\text { Std } \\
\text { Sapma }\end{array}$ & $\begin{array}{c}\text { Somut } \\
\text { Özellikler }\end{array}$ & Güvenilirlik & Heveslilik & Güven & Empati \\
\hline $\begin{array}{l}\text { Duygusal Denge } \\
\text { (Nevrotiklik) }\end{array}$ & 475 & 2,0109 & ,24817 &,$- 123^{* *}$ &,- 051 &,- 089 &,- 014 &,$- 140 * *$ \\
\hline Dişa Dönüklük & 475 & 3,7733 & ,56126 &,- 023 &,- 047 &,- 057 &,- 064 &,$- 147 * *$ \\
\hline Açıklık (Yaşantıya) & 475 & 3,8772 & ,42966 &,- 019 &,- 051 &,- 049 &,- 066 &,- 080 \\
\hline Geçimlilik (Uyumluluk) & 475 & 3,7049 & ,37503 & ,133** & ,177** & ,200** & ,115* & $236^{* *}$ \\
\hline Sorumluluk & 475 & 3,9014 & ,37789 &, 028 & ,109* &, 067 & ,109* &, $110^{*}$ \\
\hline
\end{tabular}

Tablo incelendiğinde kişilik özelliği alt boyutlarından duygusal denge (nevrotiklik) ile hizmet kalitesi alt boyutu olan somut özellikler arasında anlamlı ve negatif yönde zayıf bir ilişki olduğu görülmektedir ( $\mathrm{r}=$ $0,123, \mathrm{p}=0,007)$. Bu durumda profesyonel turist rehberlerinin duygusal denge (nevrotiklik) özelliği arttıkça turistlerin somut özellikler algisı olumsuz etkilenmektedir. 
Kişilik özelliği alt boyutlarından duygusal denge (nevrotiklik) ile hizmet kalitesi alt boyutu olan empati arasında anlamlı ve negatif yönde zayıf bir ilişki bulunmaktadır $(r=-0,140, p=0,002)$. Bu durumda profesyonel turist rehberlerinin duygusal denge (dengesizlik) özelliği arttıkça turistlerin empati algisı olumsuz etkilenmektedir.

Tabloda görüldüğü üzere kişilik özelliği alt boyutlarından dışadönüklük ile hizmet kalitesi alt boyutu olan empati arasında anlamlı ve negatif yönde zayıf bir ilişki bulunmaktadır $(r=-0,147, p=0,001)$. Bu durumda profesyonel turist rehberlerinin dışadönüklük özelliği arttıkça turistlerin empati algisı olumsuz etkilenmektedir.

Tabloya bakıldığında kişilik özelliği alt boyutlarından geçimlilik (uyumluluk) ile hizmet kalitesi alt boyutu olan somut özellikler arasında anlamlı ve pozitif yönde zayıf bir ilişki olduğu görülmektedir $(\mathrm{r}=0,133, \mathrm{p}=0,004) . \mathrm{Bu}$ durumda profesyonel turist rehberlerinin geçimlilik özelliği arttıç̧a turistlerin somut özellikler algisı olumlu etkilenmektedir. Yine tablo geçimlilik (uyumluluk) kişilik özelliği alt boyutu kapsamında incelendiğinde bu boyut ile hizmet kalitesi bütün alt boyutlarından güvenilirlik $(\mathrm{r}=0,177$, $\mathrm{p}=0,000)$, heveslilik $(\mathrm{r}=0,200, \mathrm{p}=0,000)$, güven $(\mathrm{r}=0,115, \mathrm{p}=0,012)$ ve empati $(\mathrm{r}=0,236, \mathrm{p}=0,000)$ boyutlar1 arasında anlamlı ve pozitif yönde zayıf bir ilişki olduğu görülmektedir. Bu kapsamda profesyonel turist rehberlerinin geçimlilik (uyumluluk) özelliği arttıkça turistlerin güvenilirlik, heveslilik, güven ve empati alg1s1 olumlu yönde etkilenmektedir.

Kişilik özelliği alt boyutlarından sorumluluk ile hizmet kalitesi alt boyutu olan güvenilirlik arasında anlamlı ve pozitif yönde zayıf bir ilişki bulunmaktadır $(\mathrm{r}=0,109, \mathrm{p}=0,018) . \mathrm{Bu}$ anlamda profesyonel turist rehberlerinin sorumluluk özelliği arttıkça turistlerin güvenilirlik alg1sı olumlu etkilenmektedir. Sorumluluk boyutu ile bir diğer hizmet kalitesi alt boyutu olan güven arasında anlamlı ve pozitif yönde zayıf bir ilişki bulunmaktadır $(\mathrm{r}=0,109, \mathrm{p}=0,017)$. Profesyonel turist rehberlerinin sorumluluk özelliği arttıkça turistlerin güven algısı olumlu etkilenmektedir. Hizmet kalitesi boyutlarından empatiye bakıldığında sorumluluk ile arasında anlamlı ve pozitif yönde zayıf bir ilişki olduğu tespit edilmektedir ( $r=0,110, p=0,017)$. Bu anlamda yine profesyonel turist rehberlerinin sorumluluk özelliği arttıkça turistlerin güven alg1s1 da olumlu etkilenmektedir ifadesine ulaşılabilir. Analiz sonuçlarına bakıldığında boyutların büyük çoğunluğunda anlamlı bir ilişki tespit edilmiştir bu kapsamda $\mathrm{H}_{1}$ kısmen desteklenmiştir.

\section{Turistlerin Demografik Özellikleri ile Hizmet Kalitesi Algıları Arasındaki Farklılaşma}

Katılımciların cinsiyetleri ile algilanan hizmet kalitesi boyutları arasında önemli bir farkllık olup olmadığı elde edilen veriler üzerinden araştırılmıştır. Tek örneklem t testi sonuçları Tablo 5’te verilmiştir.

Tablo 5. Hizmet Kalitesi Algısmmn Turistlerin Cinsiyetine Göre Karşzlaștırlması

\begin{tabular}{|c|c|c|c|c|c|c|}
\hline Boyutlar & Cinsiyet & $\bar{n}$ & Ortalama & Std. Sapma & $t$ & $\bar{p}$ \\
\hline \multirow{2}{*}{ Somut Özellikler } & Kadin & 166 & 3,8494 &, 62938 & \multirow[t]{2}{*}{1,158} & \multirow[t]{2}{*}{283} \\
\hline & Erkek & 309 & 3,8252 & 57987 & & \\
\hline \multirow{2}{*}{ Güvenilirlik } & Kadın & 166 & 3,8747 & ,65075 & \multirow[t]{2}{*}{,435 } & \multirow[t]{2}{*}{,510 } \\
\hline & Erkek & 309 & 3,8608 & ,89830 & & \\
\hline \multirow{2}{*}{ Heveslilik } & Kadin & 166 & 3,8645 & ,72227 & \multirow[t]{2}{*}{1,575} & \multirow[t]{2}{*}{210} \\
\hline & Erkek & 309 & 3,8811 & ,65945 & & \\
\hline \multirow{2}{*}{ Güven } & Kadın & 166 & 3,8404 & ,68929 & \multirow[t]{2}{*}{236} & \multirow[t]{2}{*}{,627 } \\
\hline & Erkek & 309 & 3,8908 & ,93975 & & \\
\hline \multirow{2}{*}{ Empati } & Kadın & 166 & 3,9169 & ,65880 & \multirow[t]{2}{*}{,662 } & \multirow[t]{2}{*}{416} \\
\hline & Erkek & 309 & 3,8816 &, 70918 & & \\
\hline \multirow{2}{*}{ Genel } & Kadin & 166 & 3,8716 & ,56518 & \multirow[t]{2}{*}{0,42} & \multirow[t]{2}{*}{,838 } \\
\hline & Erkek & 309 & 3,8682 &, 58045 & & \\
\hline
\end{tabular}

Hizmet kalitesi boyutlarının hepsinde cinsiyet ayrımı 0,05 anlamllık düzeyinde incelenmiştir. Sonuçlara göre turistlerin hizmet kalitesi her bir boyut ve genel hizmet kalitesi algisının cinsiyete göre farkll1ık göstermediği görülmüştür. Bu durumda $\mathrm{H}_{2 a}$ hipotezi desteklenmemiştir.

Katılımcıların medeni durumları ile algılanan hizmet kalitesi boyutları arasındaki farklılık incelenmiştir. Tek örneklem t testi sonuçları Tablo 6’te gösterilmektedir. 
ÖZSOY ve TAYFUN

Profesyonel Turist Rehberlerinin Kişilik Özellikleri İle Sundukları Hizmet Kalitesi Arasındaki İlişki

Tablo 6. Hižmet Kalitesi Algısının Turistlerin Medeni Durumlarına Göre Karşılaştırılması

\begin{tabular}{|c|c|c|c|c|c|c|}
\hline Boyutlar & Medeni Durum & $\mathbf{n}$ & Ortalama & Std. Sapma & $t$ & $\mathrm{p}$ \\
\hline \multirow{2}{*}{$\begin{array}{l}\text { Somut } \\
\text { Özellikler }\end{array}$} & Evli & 222 & 3,8682 & ,64769 & \multirow[t]{2}{*}{,243 } & \multirow[t]{2}{*}{, 622} \\
\hline & Bekâr & 253 & 3,8034 &, 54837 & & \\
\hline \multirow{2}{*}{ Güvenilirlik } & Evli & 222 & 3,9261 & 1,00710 & \multirow[t]{2}{*}{, 477 } & \multirow[t]{2}{*}{, 490 } \\
\hline & Bekâr & 253 & 3,8126 &, 60671 & & \\
\hline \multirow{2}{*}{ Heveslilik } & Evli & 222 & 3,8818 & ,71255 & \multirow[t]{2}{*}{,011 } & \multirow[t]{2}{*}{917} \\
\hline & Bekâr & 253 & 3,8696 & 65411 & & \\
\hline \multirow{2}{*}{ Güven } & Evli & 222 & 3,9122 & ,85296 & \multirow[t]{2}{*}{1,453} & \multirow[t]{2}{*}{,229 } \\
\hline & Bekâr & 253 & 3,8389 &, 86660 & & \\
\hline \multirow{2}{*}{ Empati } & Evli & 222 & 3,9000 & ,77629 & \multirow[t]{2}{*}{0,55} & \multirow[t]{2}{*}{,814 } \\
\hline & Bekâr & 253 & 3,8885 & 60898 & & \\
\hline \multirow{2}{*}{ Genel } & Evli & 222 & 3,8991 & ,65076 & \multirow[t]{2}{*}{857} & \multirow[t]{2}{*}{,355 } \\
\hline & Bekâr & 253 & 3,8433 & ,49810 & & \\
\hline
\end{tabular}

Genel itibariyle ortaya çıkan sonuçlara göre turistlerin genel olarak hizmet kalitesi algısının medeni duruma göre farklılık göstermediği görülmüştür. Sonuçlara göre $\mathrm{H}_{2 b}$ hipotezi desteklenmemiştir.

Tablo 7. Hižmet Kalitesi Algısının Turistlerin Daha Önce Tura Katılım Durumlarna Göre Karsılaștırlması

\begin{tabular}{|c|c|c|c|c|c|c|}
\hline Boyutlar & $\begin{array}{c}\text { Daha önce rehberli tura } \\
\text { katılım durumu }\end{array}$ & $\mathbf{n}$ & Ortalama & Std. Sapma & $\mathrm{t}$ & $\mathrm{p}$ \\
\hline \multirow{2}{*}{$\begin{array}{l}\text { Somut } \\
\text { Özellikler }\end{array}$} & Evet & 296 & 3,8243 & ,61751 & \multirow[t]{2}{*}{,640 } & \multirow[t]{2}{*}{,424 } \\
\hline & Hayır & 179 & 3,8492 &, 56303 & & \\
\hline \multirow{2}{*}{ Güvenilirlik } & Evet & 296 & 3,8338 & ,91522 & \multirow[t]{2}{*}{253} & \multirow[t]{2}{*}{,615 } \\
\hline & Hayır & 179 & 3,9184 & ,62947 & & \\
\hline \multirow{2}{*}{ Heveslilik } & Evet & 296 & 3,8395 &, 67146 & \multirow[t]{2}{*}{, 001} & \multirow[t]{2}{*}{,981 } \\
\hline & Hayır & 179 & 3,9344 & ,69525 & & \\
\hline \multirow{2}{*}{ Güven } & Evet & 296 & 3,8801 & ,94464 & \multirow[t]{2}{*}{,036 } & \multirow[t]{2}{*}{,850 } \\
\hline & Hayır & 179 & 3,8617 & ,70068 & & \\
\hline \multirow{2}{*}{ Empati } & Evet & 296 & 3,8473 & ,71131 & \multirow[t]{2}{*}{2,499} & \multirow[t]{2}{*}{, 115} \\
\hline & Hayır & 179 & 3,9709 &, 65209 & & \\
\hline \multirow{2}{*}{ Genel } & Evet & 296 & 3,8446 & ,58799 & \multirow[t]{2}{*}{0,11} & \multirow[t]{2}{*}{ 918 } \\
\hline & Hayır & 179 & 3,9104 & ,55082 & & \\
\hline
\end{tabular}

Ortaya çıkan veriler incelendiğinde göre turistlerin genel hizmet kalitesi algısının daha önce rehberli tura katılıma göre farklılık göstermediği görülmüştür. Araştırmaya katılan daha önce rehberli bir tura katılan turistlerin genel hizmet kalitesi alg1lama ortalaması 3,8446, standart sapmas1 0,58799 iken daha önce rehberli bir tura katılmayan turistlerin genel hizmet kalitesi algilama ortalamas1 3,9104, standart sapmas1 0,55082'dir. Bu sonuçlara göre turistlerin daha önce rehberli bir tura katılması ile bu turdaki turist rehberinden algıladığı hizmet kalitesi arasında bir farklılık bulunmamaktadır. Bu kapsamda $\mathrm{H}_{2 c}$ hipotezi desteklenmemiştir.

Çalışmada bulunan demografi ifadelerden çoklu değişkene sahip olduğu için yaş, eğitim durumu ve meslek değişkenlerinin hizmet kalitesine anlamlı farklılıklar ortaya koyup koymadı̆̆1 tek yönlü varyans analizi (ANOVA) testi ile ortaya konulmuştur. 
Tablo 8. Hizmet Kalitesi Algısının Turistlerin Yaș Gruplarna Göre Karșılaștımlması

\begin{tabular}{|c|c|c|c|c|c|c|}
\hline Boyutlar & Yaş & $\mathrm{n}$ & Ortalama & Std. Sapma & $\mathbf{F}$ & $\mathrm{p}$ \\
\hline \multirow{4}{*}{$\begin{array}{l}\text { Somut } \\
\text { Özellikler }\end{array}$} & 25- alt1 & 115 & 3,8043 & 0,65877 & ,414 &, 743 \\
\hline & $26-35$ & 141 & 3,8209 & 0,57889 & & \\
\hline & $36-45$ & 117 & 3,8291 & 0,53604 & & \\
\hline & 46 ve üstü & 102 & 3,8897 & 0,61998 & & \\
\hline \multirow{4}{*}{ Güvenilirlik } & 25 - alt1 & 115 & 3,9617 & 1,24925 & 1,393 & 244 \\
\hline & $26-35$ & 141 & 3,7702 & 0,62195 & & \\
\hline & $36-45$ & 117 & 3,9179 & 0,52533 & & \\
\hline & 46 ve üstü & 102 & 3,8294 & 0,71443 & & \\
\hline \multirow{4}{*}{ Heveslilik } & 25- alt1 & 115 & 3,8565 & 0,72021 & ,975 & ,404 \\
\hline & $26-35$ & 141 & 3,8369 & 0,67809 & & \\
\hline & $36-45$ & 117 & 3,9679 & 0,59771 & & \\
\hline & 46 ve üstü & 102 & 3,8431 & 0,72944 & & \\
\hline \multirow{4}{*}{ Güven } & 25- alt1 & 115 & 3,8435 & 0,69889 & 194 & ,900 \\
\hline & $26-35$ & 141 & 3,8759 & 0,87302 & & \\
\hline & $36-45$ & 117 & 3,9209 & 0,62427 & & \\
\hline & 46 ve üstü & 102 & 3,8480 & 1,18841 & & \\
\hline \multirow{4}{*}{ Empati } & 25- alt1 & 115 & 3,8835 & 0,71278 & ,593 & ,620 \\
\hline & $26-35$ & 141 & 3,9121 & 0,65656 & & \\
\hline & $36-45$ & 117 & 3,9436 & 0,67866 & & \\
\hline & 46 ve üstü & 102 & 3,8235 & 0,73190 & & \\
\hline GENEL & & 475 & 3,8694 & ,57457 & ,433 & ,729 \\
\hline
\end{tabular}

Tablo 8'de hizmet kalitesi algısına ilişkin turistlerin yaşı ile hizmet kalitesi boyutları arasındaki ilişkinin tek yönlü varyans analizi testi sonuçları verilmiştir. Bulgular incelendiğinde gruplar arasında istatistiksel olarak anlamlı bir farklılık saptanmamıştır. Hizmet kalitesi boyutlarından hiçbirinin yaşa göre farklılık göstermediği görülmüştür. Buna göre $\mathrm{H}_{2 \mathrm{~d}}$ hipotezi desteklenmemiştir.

Tablo 9. Hizmet Kalitesi Algısımın Turistlerin Mesleklerine Göre Karșılaștırlması

\begin{tabular}{|c|c|c|c|c|c|c|}
\hline Boyutlar & Meslek & $\mathrm{n}$ & Ortalama & Std. Sapma & F & $\mathrm{p}$ \\
\hline \multirow[t]{7}{*}{ Somut Özellikler } & Memur & 91 & 3,7747 & 0,59285 &, 764 &, 599 \\
\hline & Emekli & 36 & 3,8403 & 0,67916 & & \\
\hline & İşçi & 66 & 3,9242 & 0,58993 & & \\
\hline & İşsiz & 31 & 3,879 & 0,60163 & & \\
\hline & İşveren & 90 & 3,8667 & 0,43253 & & \\
\hline & Öğrenci & 111 & 3,7658 & 0,67106 & & \\
\hline & Esnaf & 39 & 3,7756 & 0,60642 & & \\
\hline \multirow[t]{7}{*}{ Güvenilirlik } & Memur & 91 & 3,7209 & 0,62743 & 992 & 430 \\
\hline & Emekli & 36 & 3,7611 & 0,73883 & & \\
\hline & İşçi & 66 & 3,8939 & 0,64328 & & \\
\hline & İşsiz & 31 & 3,9871 & 0,5909 & & \\
\hline & İşveren & 90 & 3,9067 & 0,58383 & & \\
\hline & Öğrenci & 111 & 3,9333 & 1,25404 & & \\
\hline & Esnaf & 39 & 3,7436 & 0,56186 & & \\
\hline \multirow[t]{7}{*}{ Heveslilik } & Memur & 91 & 3,8187 & 0,68826 & ,396 & ,882 \\
\hline & Emekli & 36 & 3,8264 & 0,82984 & & \\
\hline & İşçi & 66 & 3,9091 & 0,68449 & & \\
\hline & İşsiz & 31 & 3,9597 & 0,60241 & & \\
\hline & İşveren & 90 & 3,9167 & 0,59374 & & \\
\hline & Öğrenci & 111 & 3,8378 & 0,72508 & & \\
\hline & Esnaf & 39 & 3,8077 & 0,63728 & & \\
\hline \multirow[t]{7}{*}{ Güven } & Memur & 91 & 3,8132 & 0,66936 &, 550 &, 770 \\
\hline & Emekli & 36 & 4,0556 & 1,79096 & & \\
\hline & İşçi & 66 & 3,7992 & 0,62821 & & \\
\hline & İşsiz & 31 & 3,9597 & 0,6985 & & \\
\hline & İşveren & 90 & 3,8694 & 0,62848 & & \\
\hline & Öğrenci & 111 & 3,8896 & 0,95089 & & \\
\hline & Esnaf & 39 & 3,7821 & 0,56248 & & \\
\hline \multirow[t]{7}{*}{ Empati } & Memur & 91 & 3,8374 & 0,6545 &, 762 & ,600 \\
\hline & Emekli & 36 & 3,8167 & 0,90507 & & \\
\hline & İşçi & 66 & 3,9152 & 0,69199 & & \\
\hline & İşsiz & 31 & 4,0194 & 0,64365 & & \\
\hline & İşveren & 90 & 3,9689 & 0,58821 & & \\
\hline & Öğrenci & 111 & 3,827 & 0,71426 & & \\
\hline & Esnaf & 39 & 3,8154 & 0,72893 & & \\
\hline GENEL & & $464 *$ & 3,8694 &, 57457 & ,645 & ,695 \\
\hline
\end{tabular}


*: Çalışma kapsamında analizlere tabii tutulan örneklem sayısı 475'tir fakat hizmet kalitesi algısının turistlerin mesleklerine göre farklılaşmasını ölçmeye dayalı yapılan tek yönlü varyans analizinde belirtilen meslek grupları dışında kalan ve 'diğer" olarak ifade edilen 11 örneklem, 30 'un altında değer ifade ettiği için toplam örneklem sayısına dahil edilmemiştir.

Tablo 9'da turistlerin meslekleri ile hizmet kalitesi boyutları arasındaki farklilık belirlenmeye çalışılmıştır. Bu amaçla yapılan tek yönlü varyans analizi sonucunda, turistlerin meslekleri ile hizmet kalitesi boyutları arasında anlamlı bir fark bulunmamıştır. Bu kapsamda $\mathrm{H}_{2 \mathrm{e}}$ hipotezi desteklenmemiştir.

Tablo 10. Hižmet Kalitesi Algısımm Turistlerin Ë̆itim Durumlarna Göre Karşılaştırlması

\begin{tabular}{|c|c|c|c|c|c|c|}
\hline Boyutlar & Eğitim Durumu & $\mathbf{n}$ & Ortalama & Std. Sapma & $\mathbf{F}$ & $\mathrm{p}$ \\
\hline \multirow[t]{3}{*}{ Somut Özellikler } & İlköğretim & 54 & 3,9444 & 0,58007 & 1,319 & ,268 \\
\hline & Lise & 205 & 3,7976 & 0,5783 & & \\
\hline & Üniversite & 216 & 3,8403 & 0,61753 & & \\
\hline \multirow[t]{3}{*}{ Güvenilirlik } & İlköğretim & 54 & 4,0519 & 0,65264 & 1,688 & , 186 \\
\hline & Lise & 205 & 3,8224 & 0,61428 & & \\
\hline & Üniversite & 216 & 3,8602 & 1,00375 & & \\
\hline \multirow[t]{3}{*}{ Heveslilik } & İlköğretim & 54 & 4,0556 & 0,66706 & 3,335 & 036 \\
\hline & Lise & 205 & 3,8000 & 0,69593 & & \\
\hline & Üniversite & 216 & 3,9016 & 0,68135 & & \\
\hline \multirow[t]{3}{*}{ Güven } & İlköğretim & 54 & 4,0139 & 0,69434 & 1,071 & ,344 \\
\hline & Lise & 205 & 3,8244 & 1,06194 & & \\
\hline & Üniversite & 216 & 3,8843 & 0,65939 & & \\
\hline \multirow[t]{3}{*}{ Empati } & İlköğretim & 54 & 4,0519 & 0,62306 & 1,602 & ,113 \\
\hline & Lise & 205 & 3,8361 & 0,67857 & & \\
\hline & Üniversite & 216 & 3,9093 & 0,71548 & & \\
\hline GENEL & & 475 & 3,8694 &, 57457 & 2,909 &, 056 \\
\hline
\end{tabular}

Tablo 10'a bakıldığında her bir hizmet kalitesi boyutu ile turistlerin eğitim düzeyleri arasında bir farklılık olup olmadığı incelenmiştir. Hizmet kalitesi ölçeği alt gruplarından "heveslilik" boyutu ortalaması 3,8000 olarak saptanmıştır. Yapılan varyans analizine göre $(F=3,335)$ gruplar arasında istatistiksel olarak anlamlı farklılık gözlemlenmiştir ( $\mathrm{p}<0.01)$. Bu kapsamda $\mathrm{H}_{2 \mathrm{f}}$ hipotezi kısmen desteklenmiştir. Eğitim düzeyi farklılığının hangi gruplar arasında olduğunu belirlemek için posthoc testi kullanılmıştır. Genel anlamda, posthoc istatistikleri, gruplar arası varyansın eşit olması veya eşit olmaması gibi durumlarda kullanılmaktadır (Nelson, 1983). Bu kapsamda bir posthoc testi olan LSD çoklu karşılaştırma testi uygulanmiştır.

Buna göre, "heveslilik" boyutu açısından bakıldığında ilköğretim mezunu turistler ile lisansüstü eğitim düzeyinde olan turistler arasında fark olduğu tespit edilmiştir. Sonuçlara göre ilköğretim mezun grubu (X $=4,0556)$ ile üniversite mezun grubu $(X=3,9016)$ arasında ilköğretim mezun grubu lehine fark vardır.

Bulgular incelendiğinde turistlerin hizmet kalitesi algılarının demografik özelliklerine göre farklılaşmasına yönelik oluşturulan hipotezlerden yalnızca $H_{2 f}$ hipotezi kısmen desteklenmiştir. Bu kapsamda ' $H_{2}$ : Turistlerin hizmet kalitesi algılar demografik özelliklerine göre anlamlı bir sekilde farklulasmaktadır" hipotezi kısmen desteklenmiştir.

\section{Tartışma, Sonuç ve Öneriler}

Profesyonel turist rehberlerinin tur boyunca turistlere sağladığ1 hizmetin niteliği memnuniyeti etkileyen bir faktör olarak düşünülmektedir. Turist rehberinin kişilik özelliklerinin turdaki performansına yansıması durumu da turistlerin memnuniyet alg1sını değiştirebilmektedir. Turistlerin yaşadıkları yerden farklı bir bölgeye gittiklerinde kendilerini yabanc1 gibi hissetmemeleri, gezdikleri ülkelere uyum sağlayabilmeleri, bölge hakkında bilgi edinmeleri ve bölgeden memnun bir şekilde ayrılmaları hususunda turist rehberlerinin gösterdiği performansın etkisi oldukça önemlidir. Bu düşünceden yola çıkarak profesyonel turist rehberlerinin kişilik özellikleri ile hizmet kalitesi arasında bir ilişki olup olmadığ incelenmiştir. Temel amaca bağlı olarak, iki hipotez ve altı adet alt hipotez geliştirilmiştir. Bu hipotezler şu şekilde açıklanabilir; 
Tablo 11. Hipotezler

\begin{tabular}{|c|c|c|}
\hline & Hipotezler & $\begin{array}{c}\text { Desteklenme } \\
\text { Durumu }\end{array}$ \\
\hline $\mathbf{H}_{1}$ & $\begin{array}{l}\text { Turist rehberinin kişilik özellikleri ile turistlerin algıladığı hizmet kalitesi arasında anlamlı } \\
\text { bir ilişki vardır. }\end{array}$ & Kısmen desteklenmiştir \\
\hline $\mathbf{H}_{2}$ & $\begin{array}{l}\mathrm{H}_{2} \text { : Turistlerin hizmet kalitesi algıları demografik özelliklerine göre anlamlı bir şekilde } \\
\text { farklılaşmaktadır. }\end{array}$ & Kısmen desteklenmiştir \\
\hline $\mathbf{H}_{2 \mathrm{a}}$ & Turistlerin hizmet kalitesi algıları cinsiyetlerine göre anlamlı bir şekilde farklılaşmaktadır. & Desteklenmemiştir \\
\hline $\mathbf{H}_{2 b}$ & $\begin{array}{l}\text { Turistlerin hizmet kalitesi algıları medeni durumlarına göre anlamlı bir şekilde } \\
\text { farklılaşmaktadır. }\end{array}$ & Desteklenmemiştir \\
\hline $\mathbf{H}_{2 \mathrm{c}}$ & $\begin{array}{l}\text { Turistlerin hizmet kalitesi algıları daha önce rehberli bir tura katılım durumlarına göre } \\
\text { anlamlı bir şekilde farklılaşmaktadır. }\end{array}$ & Desteklenmemiştir \\
\hline $\mathbf{H}_{2 \mathrm{~d}}$ & Turistlerin hizmet kalitesi algıları yaşlarına göre anlamlı bir şekilde farklılaşmaktadır. & Desteklenmemiştir \\
\hline $\mathbf{H}_{2 \mathrm{e}}$ & Turistlerin hizmet kalitesi algıları mesleklerine göre anlamlı bir şekilde farklılaşmaktadır. & Desteklenmemiştir \\
\hline $\mathbf{H}_{2 \mathrm{f}}$ & $\begin{array}{l}\text { Turistlerin hizmet kalitesi algıları eğitim durumlarına göre anlamlı bir şekilde } \\
\text { farklılaşmaktadır. }\end{array}$ & Kismen desteklenmiştir \\
\hline
\end{tabular}

Tablo incelendiğinde iki hipotez ve $\mathrm{H}_{2 \mathrm{f}}$ alt hipotezinin kısmen desteklendiği görülmektedir. $\mathrm{H}_{2 \mathrm{f}}$ alt hipotezinin kısmen desteklenmesi turistlerin, eğitim durumlarının hizmet kalitesi algıllarını değiştirdiğini göstermektedir. Bulgular incelendiğinde ilköğretim mezunu turistler ile lisansüstü eğitim düzeyinde olan turistlerin hizmet kalitesi algıları arasında farklılık bulunmaktadır. Diğer $\mathrm{H}_{2 \mathrm{a}}, \mathrm{H}_{2 \mathrm{~b}}, \mathrm{H}_{2 \mathrm{c}}, \mathrm{H}_{2 \mathrm{~d}}$ ve $\mathrm{H}_{2 \mathrm{e}}$ alt hipotezleri desteklenmemiştir. Bu kapsamda turistlerin; cinsiyetleri, medeni durumları, daha önce rehberli bir tura katılım durumları, yaşlanı ve meslekleri, hizmet kalitesi algılarını değiştirmemektedir yargısına ulaşabiliriz.

Turist rehberlerinin kişilik özellikleri ve hizmet kalitesi alt boyutları arasındaki ilişki incelendiğinde destekleyici oranda bir ilişki tespit edilmiştir. Boyutlara bakıldığında profesyonel turist rehberlerinin duygusal denge (dengesizlik) özelliği arttıkça turistlerin somut özellikler algisı olumsuz etkilenmektedir. Buradan hareketle turistlerin, turist rehberlerinin dış görünüşüne, tur esnasında kullandığ1 ekipmanlarına olan kalite algisı turist rehberlerinin duygusal denge (dengesizlik) özelliğine göre olumsuz yönde etkilenmektedir. Bunun yanı sıra profesyonel turist rehberlerinin duygusal denge (dengesizlik) özelliği arttıkça turistlerin empati algisı da olumsuz etkilenmektedir.

Diğer bir kişilik özelliği alt boyutlarından olan dışadönüklük ile hizmet kalitesi alt boyutlarına bakıldığında, empati boyutu ile arasında anlamlı ve negatif yönde zayıf bir ilişki bulunmaktadır. Bu sonuç oldukça ilginç bir bulgudur. Çünkü turist rehberinden beklenen rol ve sorumluluklarda rehberin dişa dönük, canl, enerjik, insanlarla fazla iletişim kuran, olumlu ruh haline sahip olmaları beklenmektedir (Kong, Cheung ve Baum, 2009). Bulgular incelendiğinde turist rehberinin dişa dönük kişilik özelliğinin arttıkça, turistlerin hizmet kalitesi boyutlarından algıladığı empati özelliği olumsuz yönde seyretmektedir. Bu durumda profesyonel turist rehberlerinin dışadönüklük özelliği arttıkça turistlerin empati algısı olumsuz etkilenmektedir sonucuna ulaşılmaktadır.

Bir diğer kişilik özelliği geçimlilik (uyumluluk) incelendiğinde bu özelliğin arttıkça turistlerin güvenilirlik, heveslilik, güven ve empati algısının olumlu yönde etkilendiği görülmüștür. Yine profesyonel turist rehberlerinin sorumluluk özelliği arttıkça turistlerin, rehberlere yönelik algıladığ1 güvenilirlik, güven ve empati algisı olumlu etkilenmektedir. Bezirgan, Mercan ve Alamur'un (2015) hazırladığı çalışmada da bu bulguyu destekleyecek bir sonuca ulaşılmışır. Çalışmaya göre geçimlilik düzeyi yüksek çıkan çalsşanların tüketicilerle daha olumlu kültürel iletişim kurduğu saptanmıştır.

Turist rehberlerinin kişilik özellikleri ve hitap ettikleri turistlerin algıladıkları hizmet kalitesi arasındaki iliş̧i tespit edilmeye çalışılmışır. Bu kapsamda turist rehberlerinin kişilik özellikleri ile turistlerin algıladığ1 hizmet kalitesi algisı arasında anlamlı bir ilişki bulunmuştur. Kabakulak (2018) tarafindan gerçekleştirilen çalışmada, turist rehberlerinin kişilik özelliklerinin, meslekteki davranışları ve iş tatminleri üzerinde anlamlı bir etkisinin olduğu çalışma da bu sonucu destekler nitelik taşımaktadır. Meslekteki davranışlar ve iş tatmini, hitap edilen misafire olumlu veya olumsuz şekilde yansımaktadır (Kabakulak, 2018, s. 144).

$\mathrm{Bu}$ çalışma turist rehberlerinin kişilik özelliklerinin, turistlerin algiları üzerinde nasıl bir rolünün olduğuna ve turist rehberinin kişiliğinin nasıl olması gerektiğine yönelik eğitimcilere bir fayda sağlayabilir. Bunun yanında sektör temsilcilerine turist rehberlerinin nitelikleri ve barındırması gereken kişilik özellikleri konusunda bir kriter oluşturmak konusunda yardımcı olabilir. 
Turist rehberlerinin kişilik özellikleri ve hitap ettikleri turistlerin algıladıkları hizmet kalitesi arasındaki ilişki tespit edilmeye çalışılmıştır. Bu kapsamda gelecek çalışmalarda örneklem sayısının çoğaltılarak daha fazla turist ve turist rehberiyle iletişim sağlanabilir. Turistlerin algıladıkları hizmet kalitesinin yanında turist rehberlerinin kişilik özelliklerinin tur deneyimlerine olan etkisi incelenebilir. Yine turistlerin algiladıkları hizmet kalitesi durumunun hangi unsurlara göre şekillendiği tespit edilebilir.

\section{Etik Beyan}

"Profesyonel Turist Rehberlerinin Kişilik Özellikleri İle Sundukları Hizmet Kalitesi Arasındaki İlişki" başlıklı çalışmanın yazım sürecinde bilimsel, etik ve alıntı kurallarına uyulmuş; toplanan veriler üzerinde herhangi bir tahrifat yapılmamış ve bu çalışma herhangi başka bir akademik yayın ortamına değerlendirme için gönderilmemiştir.

\section{Kaynakça}

Altunışık, R., Coşkun, R., Bayraktaroğlu, S. ve Yıldırım, E. (2012). Sosyal bilimlerde araştırma yöntemleri (7.Basım). Sakarya: Sakarya Yayıncilik.

Ap J. ve Wong K. F. K. (2001). Case study on tour guiding: professionalism, 1ssues and problems. Tourism Management, 22, 551-563.

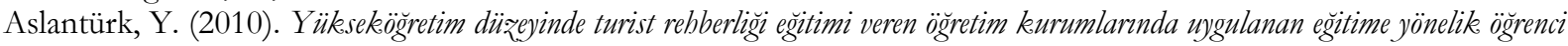
algzlamaları (Doktora Tezi). Gazi Üniversitesi Eğitim Bilimleri Enstitüsü, Ankara.

Aslantürk, Y., Altunöz, Ö. ve Çalık, A. Ö. (2013). Turist rehberliği hizmet kalitesi ölçümü: Servqual yaklaşımı. Uluslararast Sosyal Arasttrmalar Dergisi, 6(27), 107-118.

Bak, E (2015). Turist rebberlerinin performansmm turist tatminine etkisi: Kapadokya'yz ziyaret eden yabancs turistler üzerinde bir araşstrma (Yüksek Lisans Tezi). Mersin Üniversitesi Sosyal Bilimler Enstitüsü, Mersin.

Ban, J. ve Ramsaran, R. R. (2017). An exploratory examination of service quality attributes in the ecotourism industry. Journal of Travel and Tourism Marketing, 34(1), 132-148.

Butnaru, G. I., Ştefănică, M. ve Maxim, G. M. (2014). Alternative method of quality evaluation in tourism. Case study applied in tourist accommodation units. Procedia Economics and Finance, 15, 671-678.

Cohen, E., Ifergan, M. ve Cohen, E. (2002). A new paradigm in guiding The Madrich as a role model. Annals of Tourism Research, 29(4), 919-932.

Costa, P. T. ve McCrae, R. R. (1985). The NEO personality inventory. Journal of Career, 3(2), 123-139.

Costen, W. M. ve Barrash, D. I. (2006). ACE-1ng the hiring process: a customer service orientation model. Journal of Human Resources in Hospitality and Tourism, 5(1), 35-49.

Cronin, J. J. ve Taylor, S. A. (1992). Measuring service quality: A reexamination and extension. Journal of Marketing, $56(3), 55-68$.

Çelik, Ö. K. (2018). Butike otellerde sunulan bizmet kalitesinin servqual yöntemi ile ölçülmesi: Ege Bölgesi'nde bir uygulama (Yüksek Lisans Tezi). Balıkesir Üniversitesi Sosyal Bilimler Enstitüsü, Balıkesir.

Değirmencioğlu, Ö. (2001). Türkiye'de turizm rehberliği eğitimi üzerine bir araştırma. Anatolia: Turizm Arasttrmalar Dergisi, 12(2), 189-196.

Donavan, D. T. (2000). Antecedents and consequences of the contact employee's service orientation: From personality traits to service behaviors (Doktora Tezi). Oklahoma State University, Oklahoma.

Eser, S., Şahin, S. ve Çakıcı, C. (2018). Turist rebberliği. Ankara: Detay Yayıncılık.

Fettahlıoğlu, Ö. O., Polat, M. ve Demir, S. (2016). Hizmet kalitesinin servqual analizi ile ölçümü: Kahramanmaraş ilinde bir uygulama. ODÜ Sosyal Bilimler Araşttrmalar Dergisi (ODÜSOBL்AD), 6(3), 849-860.

Frew, E. A. ve Shaw, R. N. (1999). The relationship between personality, gender, and tourism behavior. Tourism Management, 20(2), 193-202.

Grönroos, C. (1984). A service quality model and 1ts marketing implications. European Journal of Marketing, 18(4), 3644.

Hartline, M. D. ve Jones, K. C. (1996). Employee performance cues in a hotel service environment: Influence on perceived service quality, value, and word-of-mouth intentions. Journal of business research, 35(3), 207-215.

Kabakulak, A. (2018). Kişilik özzelliklerinin mesleki tutum ve iş doyumuna etkisi: turist rebberleri üzerine bir arastrma (Yüksek Lisans Tezi). Afyon Kocatepe Üniversitesi Sosyal Bilimler Enstitüsü, Afyonkarahisar.

Koçoğlu, C. M. ve Aksoy, R. (2012). Hizmet kalitesinin SERVPERF yöntemi ile ölçülmesi: Otobüs işletmeleri üzerinde bir uygulama. Akademik Bakış Dergisi, 29, 1-25.

Kong, H., Cheung C. ve Baum, T. (2009). Are tour guides in China ready for thebooming tourism industry. Journal of China Tourism Research, 5, 65-76.

Lee-Ross, D. (2003). The questional relationship: service redispositions and quality assurance, managing employee attitudes and behaviors in the tourism and hospitality industry. New York: Nova Publisher.

Macionis, J. J. (2012). Sosyoloji. (Çev. V. Akan ve diğerleri). Ankara: Nobel Akademik Yayıncılık.

Mak, A. H., Wong, K. K. ve Chang, R. C. (2011). Critical issues affecting the service quality and professionalism of the tour guides in Hong Kong and Macau. Tourism Management, 32(6), 1442-1452.

MEB (2013). Konaklama ve seyahat hiæmetleri. Ankara: Milli Eğitim Bakanlğ̆1. 
Moisescu, O. I. ve Gica, O. A. (2014). The impact of service quality on customer behavioral loyalty in the case of travel agencies from Romania. Amfiteatru Economic Journal, 16(Special No. 8), 1191-1204.

Müküs, C. (2009). Doğu Anadolu Bölgesi’nde çalışan turist rehberlerinin yeterliliüi ve turist memnuniyetinin analiz̨i (Yüksek Lisans Tezi). Yüzüncüyıl Üniversitesi Sosyal Bilimler Enstitüsü, Van.

Özdamar, K. (2002). Paket programlar ile istatistike veri analiz̨. Eskişehir: Kaan Kitapevi.

Özkalp, E. (2001). Örgütsel davranıs. (6. Baskı). Eskişehir: Anadolu Üniversitesi Yayınları.

Özoğul, G. (2017). Profesyonel turist rehberlerinin kişilik özellikleri ile mesleki bağhlhk arasindaki ilişki üzerine psikolojik sermayenin aracllk etkisi (Doktora Tezi). Adnan Menderes Üniversitesi Sosyal Bilimler Enstitüsü, Aydın.

Parasuraman, A., Zeithaml, V. A. ve Berry, L. L. (1994). Reassessment of expectations as a comparison standard in measuring service quality: implications for further research. Journal of Marketing, 58(1), 111-124.

Pelit, E., Türkmen, F. ve Yarmacı, N. (2010). Turizm sektöründeki işgörenlerin kişilik özelliklerini değerlendirmeye yönelik bir araştırma. Sosyal ve Beșeri Bilimler Dergisi, 2(1), 9-16.

Randall C. ve Rollins, R. B. (2009). Visitor perceptions of the role of tour guides in natural areas. Journal of Sustainable Tourism, 17(3), 357-374.

Serçeoğlu, N. (2013). Konaklama işletmelerinde çalışan iş görenlerin kişilik özelliklerinin hizmet verme yatkınlı̆̆1 üzerindeki etkisi. Journal of Yasar University, 8(31), 5253-5273.

Bowen, D. E. ve Schneider, B. (1995). Winning the service game. Boston: Harvard Business School Press.

Teas, R. K. (1993). Expectations, performance evaluation and consumers" percetions of quality. Journal of Marketing, 57(4), 18-34.

Temizkan, S. P. ve Arı, Ö. (2019). Turist rehberi adaylarının kişilik özelliklerinin mesleğin gerekleri açısından değerlendirilmesi. Journal of Gastronomy Hospitality and Travel, 2(1), 65-79.

Tsaur, S. ve Teng, H. (2017). Exploring tour guiding styles: the perspective of tour leader roles. Tourism Management, $59,438-448$.

TUREB (2019). Ankara Rehberler Odası rehber sayıs1. Retrieved from http://www.tureb.org.tr/tr/RehberVeritabani.

WFTGA (2019). Turist rehberliği. Retrieved from http://www.wftga.org/tourist-guiding/what-tourist-guide.

Yee, L. L., Ramachandran, S., Shuib, A., Johari, S. ve Afandi, S. H. M. (2018). Factors influencing visitors' evaluation of service quality in Giant Panda Conservation Centre (GPCC), Zoo Negara. International Journal of Business \& Society, 19, 140-158.

Yıldız, R., Kuşluvan, S. ve Şenyurt, Y. (1997). Turist rehberliği öğretiminde yeni bir model: Nevşehir Turist Rehberliği Bölümü programı ve değerlendirilmesi. Erciyes Üniversitesi Nevşehir Turizm Issletmeciliği ve Otelcilik Yüksekokulu Hafta Sonu Semineri IV, 9-14.

Yilmaz, İ. (2009). Measurement of service quality in the hotel industry. Anatolia, 20(2), 375-386.

Zel, U. (2011). Kişilik ve liderlik. Ankara: Nobel Akademik Yayıncılık.

\section{EXTENDED ABSTRACT}

One of the factors that play a role in the dissatisfaction of tourists from a country is the fact that tourist guides are properly and adequately informed. In changing the prejudices of the tourist, correcting the mistakes and completing the missing information, it is very important to present the guide, to introduce the country, to refer to the relevant institutions and to establish warm communication. The performance of the tourist guides is very important for the good tour. Guide; mediator, social, communicator, interpreter and responsibility are a number of roles (Randall and Rollins, 2009, p. 359). The main task of the guide is to create a speech environment rather than providing information (Cohen, Ifergan and Cohen, 2002, p. 922). In general, the studies prepared in the field of guidance have been measures that measure the performance of the guide or focus on the roles of the guide. For this reason, the study provides the opportunity to both determine the personality characteristics of the tourist guides and to measure the satisfaction of the tourists towards the tourist guides with various personality traits. It also helps to determine the quality of service depending on the satisfaction of tourists. Determining the performance of the tourist guides through visitors and recognizing the impact of this performance on the service quality will enable this profession to develop in the future. This study can be a source of guidance in terms of providing a better service and identifying problems. In this regard, how to determine that there is a relationship between personality traits and how they're performing on the professional tour guide in Turkey is the objective of this study. In this context, it has been tried to determine how the performance level is perceived by the local tourists and to determine how this performance is reflected on the service quality. It was investigated. In the research, quantitative research method was used. The data collection tool used in the research is the survey technique which is widely used in the field of social sciences. The performance and personality traits of professional tourist guides can be easily measured with a survey technique. In addition to this, it is thought that the questionnaires are more productive as a result of the understanding of the items of the questionnaire through one-to-one mutual communication with the 
tourists and professional tourist guides. Tourist groups and professional tourist guides. Information was obtained from the tourist groups who are traveling with daily or accommodation tours depending on the travel agencies and not a specific region and professional tourist guides responsible for each group. As of 2019, 836 tourist guides are registered with the Ankara Chamber of Guides. 545 of this number consists of active tourist guides (TUREB, 2019). This number represents the tourist guide universe of the research. 13 tour guides and 475 tourists from Ankara are the sample of the research. The number of guide samples is a natural result of the tourist groups participating in the tours. What is to be measured is the quality of service in line with the satisfaction of tourists and as the number of tourist guide samples grows, so will the number of tourist samples. Therefore, the number of guide samples was determined according to the tourist sample rate. The limitation of the survey is that surveys will only be applied to local tourists for reasons such as resources, time and cost. When the relationship between personality traits and service quality sub-dimensions of tourist guides was examined, a supportive relationship was found. In terms of dimensions, as the emotional balance (imbalance) feature of professional tourist guides increases, the perception of concrete features of tourists is negatively affected. From this point of view, the perception of quality of the tourists on the external appearance of the tourist guides and the equipment's used during the tour is negatively affected according to the emotional balance (imbalance) characteristic of the tourist guides. In addition, as the emotional balance (imbalance) feature of professional tourist guides increases, the perception of empathy of tourists is also negatively affected. When extraversion, which is another subdimension of personality traits, and service quality sub-dimensions are examined, there is a significant and negative weak relationship between empathy dimensions. This result is a very interesting finding because the tourist guide is expected to have an outward, lively, energetic, more communicative, positive mood in the roles and responsibilities expected from the tourist guide (Kong, Cheung and Baum, 2009). When the findings are examined, as the outward personality of the tourist guide increases, the empathy feature perceived from the service quality dimensions of the tourists is negatively observed. In this case, as the extraversion property of professional tourist guides increases, it is concluded that the perception of empathy of tourists is adversely affected. As the responsibility of professional tourist guides increases, the perception of reliability, trust and empathy perceived by the tourists towards the guides is positively affected. The relationship between the personality traits of the tourist guides and the perceived service quality of the tourists they addressed was tried to be determined. In this context, a significant relationship was found between the personality traits of tourist guides and the perception of service quality perceived by tourists. In summary, the personality characteristics of the tourist guide affect the opinion of tourists to provide quality service to the guides. The relationship between the personality traits of the tourist guides and the perceived service quality of the tourists they addressed was tried to be determined. In this context, the number of samples can be increased in future studies and communication with more tourists and tourist guides can be provided. Besides the perceived service quality of the tourists, the effect of the personality characteristics of the tourist guides on the tour experiences can be examined. Again, it can be determined which factors shape the quality of service perceived by tourists. 